\title{
In memoriam Michael Stolleis
}

V letošním roce ztratila nejen evropská, ale můžeme směle říci, že i světová právní historie jednoho z jejích předních představitelů. Tím byl nepochybně Michael Stolleis. Člověk vždy milý, zdvořilý, s úsměvem na rtech. Jeho přednášky byly originální a nutily posluchače k zamyšlení. Jeho zásluhy o obor byly nejen ve sféře pedagogické a vědecké, ale stejně se také snažil přiblížit právní dějiny co největšímu počtu čtenářů. O jeho velké píli svědčí seznam jeho tvorby, at’ už se jedná o obsáhlé monografie, kratší studie, referáty, přednášky, recenze nebo komentáře $\mathrm{k}$ soudním rozhodnutím $\mathrm{z}$ oblasti veřejného práva. Tento seznam čítá celkem 46 stran a 552 položek (viz hlt.mpg.de/2119525/Schriften _Stolleis_Stand_2020.pdf), a to dokonce aniž by v něm byly zohledněny jeho pedagogické aktivity.

M. Stolleis se narodil v Ludwigshafenu am Rhein v roce 1941. Jeho otec, také právník, zde byl starostou a zároveň se zabýval vinařstvím. Vinařskou průpravou prošel také jeho syn, který v tomto oboru v roce 1961 složil

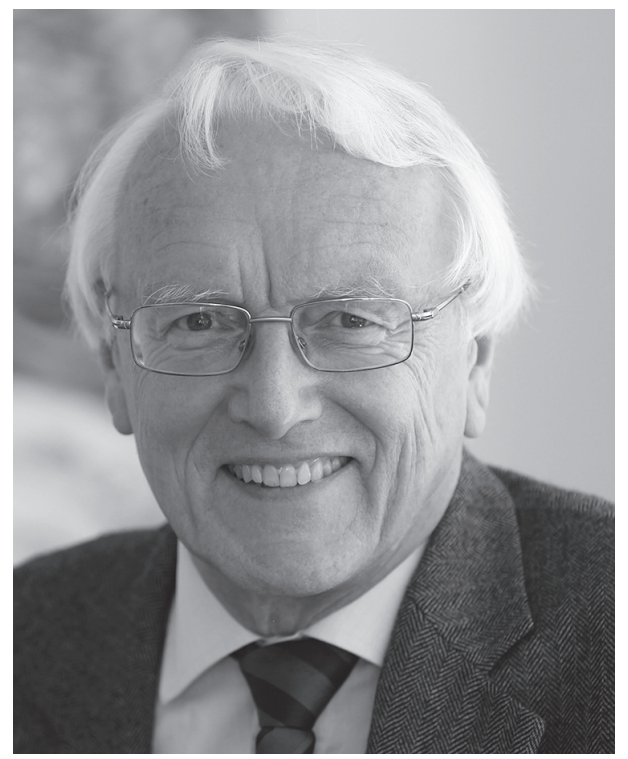

Foto: Sandra Hauer - pozdější fotografie odbornou zkoušku. Po maturitě roku 1960 začal studovat práva, německou literaturu a dějiny umění na univerzitách v Heidelbergu a Würzburgu. Doktorát získal v roce 1967 po obhajobě disertační práce „Staatsraison, Recht und Moral in philosophischen Texten des späten 18. Jahrhunderts“" na univerzitě Ludwiga Maximiliana v Mnichově u Stena Gagnéra. Jeho další kvalifikační práce - habilitační - „Gemeinwohlformeln im nationalsozialistischen Recht" se zabývala právem za národního socialismu. V roce 1974 získal M. Stolleis profesuru na Goethe-Universität ve Frankfurtu nad Mohanem. Zde působil řadu let a přednášel dějiny veřejného práva až do roku 2006. V roce 1991 obdržel celosvětově renomované ocenění své práce ve formě ceny Gottfried-Wilhelm-Leibniz-Preis der Deutschen Forschungsgemeinschaft a ve stejném roce 
se stal ředitelem Institutu Maxe Plancka pro evropskou právní historii (Max-Planck-Institut für europäische Rechtsgeschichte). Ředitelem tohoto pracoviště byl v letech 1991-2002 a do vedení této instituce se vrátil ještě v letech 2007-2009. Za svoji tvůrčí práci v oblasti právní historie a publikaci „Rechtsgeschichte der Neuzeit“ získal v roce 2000 Bolzanovu cenu.

Neúnavná vědecká a organizační činnost M. Stolleise byla oceněna rovněž v zahraničí. Byl nositelem čestných doktorátů z univerzit v Lundu, Toulouse, Padově a Helsinkách. Byl také držitelem federálního řádu za zásluhy, jediného státního vyznamenání udělovaného v SRN (kříž s hvězdou) a řádu Pour le Mérite (vicekancléř řádu). M. Stolleis byl členem mnoha vědeckých akademií, např́iklad Německé akademie př́rodních věd Leopoldina. Jeho právněhistorická produkce je velice obsáhlá a zároveň všestranná. Za všechny publikace můžeme jmenovat čtyřsvazkové dílo „Geschichte des öffentlichen Rechts in Deutschland“ (1988-2012). Tyto dějiny veřejného práva byly původně koncipované jako jednosvazkový protějšek obsáhlých dějin soukromého práva Franze Wieackera („Privatrechtsgeschichte der Neuzeit unter besonderer Berücksichtigung der deutschen Entwicklung“, 1952, reed. 1967, 1996, 2016). Stolleisova práce je vysoce erudovaným popisem ius publicum mezi lety 1600 a 1990 . Veden pevným rozhodnutím vyhnout se psaní intelektuální historie velkých myslitelů, nebo př́běhů o postupném pokroku veřejného práva, zkoumal až do nejmenších podrobností institucionální souvislosti poznání, historii vztahů mezi právem a politikou, literární dějiny, ústavní dějiny a dějiny idejí v průběhu čtyř století. Př́nos této publikace zhodnotil prof. Dr. Thomas Duve (̌reditel Max-Planck-Institut für Rechtsgeschichte und Rechtstheorie) takto: „Pro právní historii, tradičně zaměřenou na soukromé právo, tato práce otevřela nový svět.“ Dále k tomu říká, že „Michael Stolleis nebyl jen výjimečnou osobností právního historika veřejného práva, raného novověku a moderní doby, ale i soudobých právních dějin. Od začátku devadesátých let formoval Institut Maxe Plancka pro evropskou právní historii také těmito výzkumnými oblastmi, ale v neposlední řadě svou osobností. Byl mentorem, podporovatelem a vzorem pro mladé vědce z celého světa. Angažovaný pozorovatel a vzdělaný interpret práva.“ Tato jeho výše uvedená klíčová publikace, stejně jako řada dalších, byla přeložena nejen do angličtiny, ale i španělštiny, italštiny, čínštiny, estonštiny, francouzštiny, japonštiny a dalších jazyků.

Poněkud jiný charakter pak má jeho publikace „Das Auge des Gesetzes. Geschichte einer Metapher“ (Oko zákona, historie jedné metafory) z roku 2004, která se zabývá vztahem mezi právem a spravedlností v širším společensko-historickém kontextu. Také tato práce byla přeložena do řady cizích jazyků. Na počátku 90. let minulého století, s nimiž je spojeno nové směřování Max-Planck Institutu, se blíže věnoval i otázkám fungování a transformace práva ve státech střední a východní Evropy a zároveň inicioval také některé výzkumné projekty, jako např́klad „The Formation of Normative Orders“, které se touto problematikou zabývají. M. Stolleis se stal neodmyslitelnou součástí nejen německé, ale také evropské právní historie, mezi jejíž vůdčí osobnosti patřil.

Petra Skřejpková

doi: 10.14712/2464689X.2021.39 